\title{
Hubungan Antar Faktor Penyebab Human Error Terhadap Jumlah Penyimpangan Produk Blister Di PT. XXX
}

\author{
Nurliya Irfiani ${ }^{1}$, Aditya Trias Pradana ${ }^{2}$, dan Agnes Nuniek Winantari² \\ ${ }^{1}$ Program Studi Magister Farmasi, Fakultas Farmasi, Universitas Surabaya \\ ${ }^{2}$ Laboratorium Farmasetika, Fakultas Farmasi, Universitas Surabaya \\ Korespondensi: Nurliya Irfiani \\ Email: nurliya_ffua@yahoo.com
}

Submitted: 01-10-2018, Revised : 18-10-2018, Accepted : 20-12-2018

\begin{abstract}
ABSTRAK: Human error merupakan penyebab utama terjadinya penyimpangan mutu produk blister di PT. XXX, yang dipengaruhi oleh faktor personil dan metode kerja. Penelitian ini bertujuan untuk menganalisis hubungan level kualifikasi personil (tim produksi blister) dan jumlah produk blister serta lama produksi (mesin blister Z) terhadap peningkatan penyimpangan produk blister di PT. XXX (2015-2017). Penelitian ini bersifat deskriptif observasional (retrospektif) menggunakan analisis regresi linier 2 variabel dan multi variabel. Hasil analisis uji t antara level kualifikasi personil dan penyimpangan produk blister, $\mathrm{p}=0,041(\mathrm{p}<0,05)$ menunjukkan hubungan signifikan antara kedua variabel tersebut. Hasil analisis uji $\mathrm{t}$ antara jumlah produk blister dan penyimpangan produk blister, $\mathrm{p}=0,164(\mathrm{p}>0,05)$ menunjukkan tidak terdapat hubungan signifikan antara kedua variabel tersebut. Hasil analisis uji t antara lama produksi (mesin blister Z) dan penyimpangan produk blister, $p=0,542(p>0,05)$ menunjukkan tidak terdapat hubungan signifikan antara kedua variabel tersebut. Hasil analisis uji F menunjukkan terdapat hubungan signifikan antara level kualifikasi personil (tim produksi blister) dan jumlah produk blister serta lama produksi (mesin blister Z) terhadap peningkatan penyimpangan produk blister $(p=0,000 ; p<0,05)$.
\end{abstract}

Kata Kunci: Human error; kualifikasi personil; metode kerja; penyimpangan mutu

\begin{abstract}
Human error is the main cause of blister product quality deviation at PT. XXX, which lead by personnel factor and work method. The research intends to analyze the relationship between personnel qualification level (blister production team), number of blister product and production length (Z blister machine), with blister product deviation at PT. XXX (2015-2017). The research was a descriptive-observational study (retrospective) by linier regression analysis using 2 variables and multi variables. The t-test analysis result between personnel qualification level and blister product deviation, $p=0.041(p<0.05)$ showed a significant relationship between those variables. The t-test analysis result between number of blister product and blister product deviation, $p=0.164$ ( $p>0.05)$ showed that there is no significant relationship between those variables. The result of $t$-test between production length ( $Z$ blister machine) and blister product deviation, $p=0.542$ $(p>0.05)$ showed that there is no significant relationship between those variables. The F-test analysis result showed a significant relationship between personnel qualification level (blister production team), number of blister product and production length (Z blister machine) with blister product deviation $(p=0.000 ; p<0.05)$.
\end{abstract}

Keywords: Human error; personnel qualification; work method; quality deviation 


\section{Pendahuluan}

Berdasarkan CРOB 2012, industri farmasi harus membuat obat sedemikian rupa agar sesuai dengan tujuan penggunaannya, memenuhi persyaratan yang tercantum dalam dokumen izin edar (registrasi) dan tidak menimbulkan risiko yang membahayakan penggunanya karena tidak aman, mutu rendah atau tidak efektif. Untuk mencapai tujuan mutu secara konsisten dan dapat diandalkan, diperlukan sistem pemastian mutu yang didesain secara menyeluruh dan diterapkan secara benar. Hal ini hendaklah didokumentasikan dan dimonitor efektivitasnya [1].

Salah satu bentuk upaya pencapaian mutu yang diterapkan di industri farmasi adalah mengurangi penyimpangan dan pencegahan keterulangan penyimpangan. Penyimpangan merupakan kondisi yang dapat menyebabkan produk tidak sesuai dengan persyaratan mutu, ketidakefisienan proses produksi karena proses dihentikan sementara untuk melakukan investigasi serta tindakan perbaikan, dan bila terjadi berulang akan dapat meningkatkan risiko mutu hingga terjadinya penarikan produk $[1,2]$.

Berdasarkan data penyimpangan di PT. XXX pada tahun 2015 hingga 2017, jumlah penyimpangan yang terjadi pada proses produksi blister mencapai rata-rata $>100$ penyimpangan dari total 400 penyimpangan $[3,4,5]$. Proses investigasi dan penentuan Corrective Action \& Preventive Action (CAPA) pada setiap penyimpangan telah dilakukan selama kurun waktu tersebut namun jumlah penyimpangan yang terjadi masih cukup tinggi dari target perusahaan berupa penurunan $30 \%$ setiap tahunnya. Kondisi ini harus segera dikendalikan agar tidak meningkatkan risiko mutu lebih lanjut yang mengarah pada sanksi badan regulasi saat dilakukan inspeksi rutin maupun kejadian yang tidak diharapkan yaitu penarikan produk. Menurut referensi, $h u-$ man error merupakan salah satu penyebab yang paling sering menimbulkan cacat kualitas pada produk yang berpotensi menimbulkan penarikan produk. Sebanyak 90\% kasus penarikan produk terkait pengemasan dan penandaan produk disebabkan karena human error [2].

Berdasarkan laporan evaluasi mutu PT. XXX pada tahun 2015 hingga 2017, data monitoring penyimpangan, penyebab terbesar terjadinya penyimpangan adalah karena human error, mencapai $44-51 \%$ dari total penyebab penyimpangan. Analisa tambahan yang sudah dilakukan, menunjukkan kasus human error terjadi karena attention gap personil saat bekerja yang mencapai 38$45 \%$ dari total kasus human error. Melalui human error checklist data di PT. XXX, diketahui sumber penyebab attention gap adalah personil terlewat melakukan tahapan kerja yang harus dilakukan, kurangnya ketelitian, terdapat gangguan saat melakukan pekerjaan, dan melakukan beberapa pekerjaan pada saat bersamaan $[3,4,5]$.

Pada kondisi saat ini, PT. XXX belum melakukan evaluasi lebih lanjut terkait faktor pencetus dari sumber penyebab human error yang disebabkan karena kesalahan interpretasi prosedur. Evaluasi baru sampai pada tahapan penentuan kategori penyebab di atas, dan fakta terkait jumlah penyimpangan yang masih terus meningkat dalam kurun waktu 2015-2017 [3, 4, 5] menunjukkan investigasi beserta CAPA tidak cukup efektif untuk mengurangi terjadinya penyimpangan, sebagai dampak analisis faktor penyebab yang belum optimal.

Sejak tahun 2015 terjadi peningkatan volume produksi blister dengan adanya penambahan pasar distribusi. Dari tahun 2015 hingga 2017 rata-rata volume produksi mencapai 7.000 .000 EA (perkiraan $70 \%$ dari total volume produksi) [6]. Produk tersebut merupakan produk inovator, beberapa di antara nya masih dalam paten yang merupakan produk untuk terapi penyakit kronis dan life-saving [7]. Ditinjau dari aspek distribusi, produk ini dipasarkan ke Indonesia, beberapa negara Asia Pasifik, dan Australia-New Zealand. Berdasarkan kondisi tersebut mutu produk yang dihasilkan sangat ditentukan dari persyaratan pasar. Adanya penyimpangan mutu yang timbul selama proses produksi menyebabkan produk tidak dapat diluluskan sampai penyimpangan di- 
selesaikan sehingga berdampak pada waktu ketersediaan produk. Produk yang tidak dapat disediakan sesuai kebutuhan dalam waktu singkat dan biaya yang terjangkau, merupakan tantangan lanjutan dalam rantai suplai. Pada keadaan ini, jumlah penyimpangan dan penyimpangan berulang merupakan hal yang harus dieliminasi agar rantai suplai tidak terganggu dan mengurangi biaya tambahan akibat melakukan investigasi maupun resiko temuan audit serta penarikan produk $[1,6]$.

Berdasarkan data evaluasi penyimpangan yang telah dilakukan di PT. XXX, human error yang disebabkan karena kesalahan interpretasi prosedur adalah penyebab utama, dengan mengacu pada sumber penyebab yang telah diuraikan sebelumnya, faktor personil dan metode kerja memiliki kaitan paling dekat. Pada СРОВ 2012, bab terkait personalia, disebutkan bahwa Industri farmasi hendaklah memiliki personil yang terkualifikasi dan berpengalaman praktis dalam jumlah yang memadai. Tiap personil hendaklah tidak dibebani tanggung jawab yang berlebihan untuk menghindarkan risiko terhadap mutu obat [1]. Pada proses produksi blister di PT. XXX, 1 tim produksi terdiri dari personil dengan level kualifikasi level 2, 3, dan 4 (level kualifikasi yang dapat bekerja mandiri tanpa pengawasan) [8]. Formasi tim ini bersifat dinamis setiap waktu, namun selalu terdiri atas 3 level kualifikasi tersebut. Proses produksi dijalankan dalam 3 periode waktu kerja dengan mesin semi-otomatis menggunakan mesin blister Z, yang menghasilkan beberapa jenis produk blister. Ditinjau dari evaluasi di atas, faktor mesin dan jenis produk blister merupakan variabel terkendali. Sehubungan persyaratan CPOB 2012 tentang personalia, proses produksi blister dan data evaluasi penyimpangan sebelumnya, menunjukkan level kualifikasi personil pada tim produksi blister serta metode kerja dilihat dari jumlah produk blister dan lama produksi dengan mesin blister $\mathrm{Z}$ berkaitan dengan risiko mutu yang melatarbelakangi terjadinya penyimpangan produk blister. Level kualifikasi yang dinamis pada tim produksi akan tetap terwakili dengan penggunaan data selama kurun waktu 2015-2017, mengingat pada periode tersebut tim produksi juga terdiri atas 3 level kualifikasi dengan formasi dinamis mengikuti jumlah personil yang terkualifikasi sesuai dengan prosedur yang diterapkan di PT. XXX.

Tujuan dari penelitian ini adalah pertama, mendapatkan hubungan signifikan antara level kualifikasi personil pada tim produksi blister dan jumlah produk blister serta lama produksi dengan mesin blister $\mathrm{Z}$ terhadap peningkatan penyimpangan produk blister di PT. XXX selama periode tahun 2015 hingga 2017. Kedua, merumuskan usulan perbaikan untuk menurunkan jumlah penyimpangan produk blister di PT. XXX.

\section{Metode}

Jenis penelitian ini adalah penelitian deskriptif observasional menggunakan data sekunder (retrospektif). Variabel pada penelitian ini adalah level kualifikasi personil pada tim produksi blister, jumlah produk blister, lama produksi dengan mesin blister $\mathrm{Z}$ dan jumlah penyimpangan mutu. Penelitian dilakukan di PT. XXX yang merupakan salah satu perusahaan farmasi multinasional yang berlokasi di propinsi Jawa Timur. Obyek penelitian adalah penyimpangan mutu yang terjadi di produk blister selama periode 20152017. Pada penelitian ini sampel diambil dengan menggunakan teknik purposive sampling. Sesuai dengan tujuan penelitian, sampel yang dipilih adalah sampel kejadian penyimpangan mutu produk blister dalam periode tahun 2015-2017, yang terkait dengan faktor penyebab human error sesuai dengan klasifikasi pada prosedur pengendalian penyimpangan PT. XXX.

Pengambilan data dilakukan dengan menggunakan formulir pengumpulan data untuk kemudahan pengambilan informasi pada dokumen sumber data. Data dikelompokkan per bulan sehingga didapatkan 36 data untuk masing-masing variabel. Data yang sudah terkumpul kemudian dilakukan analisis. Analisis regresi linier dipilih untuk menganalisis hubungan naik/turunnya 
variabel terikat dipengaruhi oleh naik/turunnya keadaan variabel bebas [9].

Pada penelitian ini analisis regresi linier menggunakan SPSS versi 22 dengan taraf signifikansi (p) 5\%. Analisis hubungan masing-masing variabel bebas terhadap variabel terikat dilakukan dengan analisis regresi linier 2 variabel melalui uji t (uji signifikansi parameter individual) [9], sedangkan analisis hubungan simultan semua variabel bebas terhadap variabel terikat dilakukan dengan analisis regresi linier berganda melalui uji F (uji signifikansi simultan) [10]. Uji prasyarat analisis (uji asumsi klasik) dilakukan lebih dahulu untuk memenuhi persyaratan analisis regresi linier, yang terdiri atas uji normalitas, heteroskedastisitas, multikolinieritas dan autokorelasi (untuk data time series) [10,11]. Uji normalitas dilakukan dengan metode Shapiro-Wilk karena sampel penelitian yang digunakan sejumlah 36 data ( $<50$ data) [12, 13]. Uji heteroskedastisitas dilakukan dengan metode Glejser dan uji autokorelasi dilakukan dengan metode Run Test.

\section{Hasil dan pembahasan}

Berdasarkan data penelitian, diketahui level kualifikasi personil pada tim produksi blister pada tahun 2015 tidak banyak yang berada pada level 2, 3 dan 4 sesuai dengan persyaratan kualifikasi personil yang dapat bekerja mandiri menurut prosedur PT. XXX. Ditinjau dari jumlah produksi blister yang dihasilkan pada tahun tersebut sebesar 1082 produk, tahun 2016 sebesar 1348 produk, dan tahun 2017 sebesar 1239 produk menunjukkan proses produksi berjalan normal meskipun level kualifikasi personil yang bekerja tidak banyak yang berada pada level dapat bekerja mandiri. Pada saat ini prosedur kualifikasi personil yang menaungi proses ini telah berada pada revisi keempat [8]. Melalui informasi yang terdapat pada riwayat revisi prosedur tersebut, diketahui bahwa prosedur kualifikasi personil baru efektif pada 31 Maret 2016 [8]. Tetapi personil telah mendapatkan pelatihan mengenai prosedur kerja terkait pekerjaan rutinnya sebelum melakukan pekerjaan, yang dikontrol dan diawasi oleh pengawas produksi. Hal ini menunjukkan sebelum prosedur ini efektif, terdapat proses pemastian personil yang bekerja telah diberi pelatihan sebelum bekerja meskipun belum melalui proses kualifikasi. Kondisi ini terjadi pula untuk data kualifikasi tahun 2016 (bulan Januari-Juli), yang berdasarkan daftar periode waktu kerja dibutuhkan sedikitnya 10 personil untuk menjalankan proses produksi, sementara prosedur kualifikasi baru efektif pada 31 Maret 2016. Selama periode tahun 2015-2017, tidak banyak personil baru yang bekerja di proses produksi blister. Hal ini menunjukkan pada periode tahun 2015 hingga 2016, personil yang mengalami peningkatan level kualifikasi level 2, 3 atau 4 merupakan personil yang sama (tabel 1, 2, dan 3).

Berdasarkan data penelitian, variabel level kualifikasi personil pada tim produksi blister merupakan data yang berupa rangkaian waktu. Data tersebut mengandung data level kualifikasi personil yang bekerja pada tahun 2015-2017 dengan komposisi personil sama sesuai uraian sebelumnya, sehingga harus melalui uji autokorelasi sebagai prasyarat analisis. Berdasarkan hasil uji prasyarat analisis, uji normalitas, heteroskedastisitas, multikolinieritas dan autokorelasi memenuhi syarat dengan taraf signifikansi 5\% menggunakan SPSS versi 22. Hal ini menunjukkan data yang digunakan memenuhi persyaratan asumsi klasik untuk analisis regresi linier.

Berdasarkan hasil analisis uji t antara level kualifikasi personil dan penyimpangan produk blister, nilai signifikansi (p) sebesar 0,041 $(p<0,05)$ menunjukkan terdapat hubungan signifikan antara level kualifikasi personil pada tim produksi blister terhadap peningkatan penyimpangan produk blister selama periode tahun 2015 hingga 2017. Hal ini berkaitan dengan data evaluasi penyimpangan yang telah dilakukan di PT. XXX, human error yang disebabkan karena 
Tabel 1. Level kualifikasi personil tim produksi blister tahun 2015

\begin{tabular}{lllll}
\hline Bulan & Level 2 & Level 3 & Level 4 & Jumlah Total \\
\hline Januari & 0 & 0 & 0 & 0 \\
Februari & 0 & 0 & 0 & 0 \\
Maret & 0 & 0 & 0 & 0 \\
April & 0 & 0 & 0 & 0 \\
Mei & 0 & 0 & 0 & 0 \\
Juni & 0 & 0 & 0 & 0 \\
Juli & 0 & 0 & 1 & 1 \\
Agustus & 0 & 0 & 1 & 1 \\
September & 0 & 0 & 1 & 1 \\
Oktober & 0 & 0 & 1 & 1 \\
November & 5 & 0 & 1 & 6 \\
Desember & 7 & 0 & 1 & 8 \\
\hline
\end{tabular}

Tabel 2. Level kualifikasi personil tim produksi blister tahun 2016

\begin{tabular}{lllll}
\hline Bulan & Level 2 & Level 3 & Level 4 & Jumlah Total \\
\hline Januari & 7 & 0 & 1 & 8 \\
Februari & 7 & 0 & 1 & 8 \\
Maret & 7 & 0 & 1 & 8 \\
April & 7 & 0 & 1 & 8 \\
Mei & 7 & 0 & 1 & 8 \\
Juni & 8 & 0 & 1 & 9 \\
Juli & 8 & 0 & 1 & 9 \\
Agustus & 4 & 7 & 1 & 12 \\
September & 4 & 7 & 1 & 12 \\
Oktober & 8 & 10 & 1 & 21 \\
November & 10 & 10 & 1 & 27 \\
Desember & 16 & 10 & 1 & \\
\hline
\end{tabular}

Tabel 3. Level kualifikasi personil tim produksi blister tahun 2017

\begin{tabular}{lllll}
\hline Bulan & Level 2 & Level 3 & Level 4 & Jumlah Total \\
\hline Januari & 21 & 10 & 1 & 32 \\
Februari & 21 & 10 & 1 & 32 \\
\hline Maret & 21 & 10 & 1 & 32 \\
\hline April & 52 & 10 & 1 & 63 \\
\hline Mei & 52 & 10 & 1 & 63 \\
Juni & 58 & 10 & 1 & 69 \\
\hline Juli & 58 & 10 & 1 & 69 \\
Agustus & 58 & 10 & 1 & 69 \\
\hline September & 58 & 10 & 1 & 69 \\
Oktober & 58 & 10 & 1 & 69 \\
\hline November & 58 & 10 & 1 & 69 \\
Desember & 58 & 10 & 1 & 69 \\
\hline
\end{tabular}


Tabel 4. Jumlah produk blister (batch) tahun 2015-2017

\begin{tabular}{llll}
\hline Bulan & $\mathbf{2 0 1 5}$ & $\mathbf{2 0 1 6}$ & $\mathbf{2 0 1 7}$ \\
\hline Januari & 79 & 112 & 59 \\
Februari & 66 & 85 & 157 \\
Maret & 85 & 106 & 133 \\
\hline April & 115 & 118 & 113 \\
Mei & 91 & 73 & 163 \\
Juni & 105 & 148 & 106 \\
Juli & 92 & 98 & 50 \\
Agustus & 75 & 121 & 139 \\
September & 98 & 128 & 85 \\
\hline Oktober & 107 & 146 & 83 \\
\hline November & 84 & 140 & 101 \\
Desember & 85 & 73 & 50 \\
\hline
\end{tabular}

Tabel 5. Lama produksi produk blister (jam) tahun 2015-2017

\begin{tabular}{llll}
\hline Bulan & $\mathbf{2 0 1 5}$ & $\mathbf{2 0 1 6}$ & $\mathbf{2 0 1 7}$ \\
\hline Januari & 655,11 & 1165,58 & 326,98 \\
\hline Februari & 405,37 & 705,99 & 1080,55 \\
\hline Maret & 679,68 & 935,90 & 810,51 \\
\hline April & 962,17 & 1029,40 & 700,34 \\
Mei & 789,19 & 673,04 & 874,62 \\
\hline Juni & 880,24 & 984,83 & 700,03 \\
Juli & 889,37 & 839,59 & 184,27 \\
Agustus & 601,91 & 866,44 & 1221,81 \\
September & 862,11 & 1080,60 & 462,13 \\
Oktober & 1046,81 & 902,55 & 437,80 \\
\hline November & 750,40 & 1239,84 & 668,59 \\
Desember & 689,09 & 550,56 & 390,26 \\
\hline
\end{tabular}

Tabel 6. Jumlah penyimpangan produk blister tahun 2015-2017

\begin{tabular}{llll}
\hline Bulan & $\mathbf{2 0 1 5}$ & $\mathbf{2 0 1 6}$ & $\mathbf{2 0 1 7}$ \\
\hline Januari & 15 & 9 & 11 \\
Februari & 10 & 13 & 19 \\
Maret & 18 & 18 & 17 \\
April & 20 & 16 & 16 \\
Mei & 15 & 12 & 16 \\
Juni & 16 & 16 & 10 \\
Juli & 13 & 7 & 1 \\
Agustus & 13 & 13 & 14 \\
September & 17 & 14 & 8 \\
Oktober & 20 & 6 & 11 \\
November & 9 & 18 & 5 \\
Desember & 8 & 6 & 6 \\
\hline
\end{tabular}


kesalahan interpretasi prosedur adalah penyebab utama, dengan mengacu pada sumber penyebab yang telah diuraikan sebelumnya, faktor personil terbukti memiliki hubungan signifikan dalam terciptanya kondisi tersebut. Ditinjau dari persyaratan СРОВ 2012, bab terkait personalia, disebutkan bahwa Industri farmasi hendaklah memiliki personil yang terkualifikasi dan berpengalaman praktis dalam jumlah yang memadai untuk menghindarkan risiko terhadap mutu obat [1]. Hasil uji di atas membuktikan pula faktor personil yang terkualifikasi berhubungan signifikan terhadap risiko mutu obat, melalui terjadinya penyimpangan mutu. Hasil uji prasyarat analisis pada uji autokorelasi yang memenuhi syarat menunjukkan level kualifikasi yang dinamis pada tim produksi terwakili dengan penggunaan data selama kurun waktu 2015-2017 sehingga persamaan regresi yang dihasilkan dapat digunakan untuk memperkirakan kondisi semua variabel yang diteliti di penelitian ini pada periode diluar tahun 2015-2017.

Berdasarkan hasil analisis uji t antara jumlah produk blister (tabel 4) dan penyimpangan produk blister (tabel 6), nilai signifikansi (p) sebesar 0,164 ( $p>0,05)$ menunjukkan tidak terdapat hubungan signifikan antara jumlah produk blister terhadap peningkatan penyimpangan produk blister selama periode tahun 2015 hingga 2017. Hal ini dimungkinkan jumlah personil yang bekerja di proses produksi blister berada pada jumlah yang cukup dalam pengaturan periode waktu kerja sesuai proses yang berlaku di PT. XXX dan relevan dengan persyaratan СРОВ 2012, bab terkait personalia, yang menyebutkan bahwa tiap personil hendaklah tidak dibebani tanggung jawab yang berlebihan untuk menghindarkan risiko terhadap mutu obat [1].

Berdasarkan hasil analisis uji $\mathrm{t}$ antara lama produksi (tabel 5) dengan mesin blister $\mathrm{Z}$ dan penyimpangan produk (tabel 6) nilai signifikansi (p) sebesar 0,542 ( $p>0,05$ ) menunjukkan tidak terdapat hubungan signifikan antara lama produksi dengan mesin blister Z terhadap peningkatan penyimpangan produk blister selama periode tahun 2015 hingga 2017. Hal ini relevan dengan hasil uji sebelumnya yang juga menunjukkan tidak terdapat hubungan signifikan antara jumlah produk blister terhadap peningkatan penyimpangan produk blister, melalui evaluasi yang sama terkait jumlah personil yang bekerja di proses produksi blister berada pada jumlah yang cukup dalam pengaturan periode waktu kerja sesuai desain proses. Pada kondisi tersebut personil memiliki waktu istirahat yang cukup sehingga tidak terbebani dengan tanggung jawab yang berlebihan, sehingga terhindar dari resiko penyimpangan mutu. Berdasarkan aspek performa mesin produksi, mesin blister $\mathrm{Z}$ telah dikualifikasi sebelum digunakan, selama penggunaan dilakukan periodik pemeriksaan dan pemeliharaan, serta parameter kritis telah dikalibrasi [14, 15]. Melalui kondisi tersebut, metode kerja yang diwakili oleh jumlah produk dan lama produksi tidak mempengaruhi penyimpangan mutu.

Berdasarkan hasil analisis uji F secara simultan antara level kualifikasi personil pada tim produksi blister serta jumlah produk blister dan lama produksi dengan mesin blister $\mathrm{Z}$, terhadap peningkatan penyimpangan produk blister, nilai signifikansi (p) sebesar 0,000 $(\mathrm{p}<0,05)$ menunjukkan terdapat hubungan signifikan antara level kualifikasi personil pada tim produksi blister serta jumlah produk blister dan lama produksi dengan mesin blister $\mathrm{Z}$ terhadap peningkatan penyimpangan produk blister selama periode tahun 2015 hingga 2017. Hal ini mengindikasikan adanya relevansi antara persyaratan СРОВ 2012 tentang personalia, proses produksi blister dan data evaluasi penyimpangan PT. XXX sebelumnya, yang menunjukkan level kualifikasi personil pada tim produksi blister serta metode kerja dilihat dari jumlah produk blister dan lama produksi dengan mesin blister $\mathrm{Z}$ berkaitan dengan resiko mutu yang melatarbelakangi terjadinya penyimpangan produk blister. 
Hasil analisis regresi berganda menggunakan interpretasi persamaan regresi menggunakan standardized beta dari hasil SPSS untuk mengeliminasi perbedaan unit ukuran pada variabel bebas [10]. Variabel bebas yang digunakan pada penelitian ini memiliki unit ukuran yang berbeda, level kualifikasi personil menggunakan unit ukuran personil, jumlah produk blister menggunakan unit ukuran batch dan lama produksi dengan mesin blister Z menggunakan unit ukuran jam. Berdasarkan nilai koefisien standardized beta yang dihasilkan dari analisis regresi berganda, rumusan persamaan regresinya menjadi :

$$
Y=-0,352 X 1+0,373 X 2+0,172 X 3
$$

Persamaan tersebut menunjukkan bahwa nilai koefisien X1 sebesar -0,352 yang mengindikasikan apabila level kualifikasi personil pada tim produksi blister (X1) meningkat 1 poin maka penyimpangan produk blister di PT. XXX (Y) akan menurun sebesar 0,352 poin, dengan asumsi X2 dan X3 tetap. Koefisien X2 sebesar 0,373 mengindikasikan apabila jumlah produk blister (X2) meningkat 1 poin maka penyimpangan produk blister di PT. XXX (Y) akan meningkat sebesar 0,373 poin, dengan asumsi X1 dan X3 tetap. Koefisien X3 sebesar 0,172 mengindikasikan apabila lama produksi dengan mesin blister Z (X3) meningkat 1 poin maka penyimpangan produk blister di PT. XXX (Y) akan meningkat sebesar 0,172 poin, dengan asumsi X1 dan X2 tetap. Berdasarkan kegunaannya, hubungan matematis persamaan regresi dapat digunakan untuk memperkirakan nilai variabel bebas dan variabel tergantung [16]. Pada aplikasinya di proses produksi blister PT. XXX, persamaan regresi yang dihasilkan dapat digunakan sebagai model untuk memperkirakan jumlah total personil yang berada pada level kualifikasi 2, 3 dan 4 yang dibutuhkan untuk mengurangi penyimpangan mutu, sinergi dengan jumlah produk dan lama kerja dalam produksi blister.

\section{Kesimpulan}

Berdasarkan hasil penelitian dapat ditarik beberapa kesimpulan antara lain, terdapat hubungan yang signifikan antara level kualifikasi personil pada tim produksi blister terhadap peningkatan penyimpangan produk blister di PT. XXX selama periode tahun 2015 hingga 2017. Terdapat hubungan tidak signifikan antara jumlah produk blister terhadap peningkatan penyimpangan produk blister di PT. XXX selama periode tahun 2015 hingga 2017. Terdapat hubungan tidak signifikan antara lama produksi dengan mesin blister Z terhadap peningkatan penyimpangan produk blister di PT. XXX selama periode tahun 2015 hingga 2017. Terdapat hubungan signifikan antara level kualifikasi personil pada tim produksi blister serta jumlah produk blister dan lama produksi dengan mesin blister $\mathrm{Z}$ secara simultan terhadap peningkatan penyimpangan produk blister di PT. XXX selama periode tahun 2015 hingga 2017.

Melalui kesimpulan di atas, aplikasi persamaan regresi yang dihasilkan dari penelitian ini dapat digunakan sebagai model dalam memperkirakan jumlah total personil yang berada pada level kualifikasi 2, 3 dan 4 yang dibutuhkan di proses produksi blister PT. XXX untuk mengurangi penyimpangan mutu, sinergi dengan jumlah produk dan lama kerja proses produksi blister. PT. XXX perlu mempertimbangkan level kualifikasi personil dalam formasi tim proses produksi blister yang dibutuhkan pada perencanaan proses produksi. Perlu dilakukan penelitian lebih lanjut untuk proses produksi lain di PT. XXX dengan model penelitian serupa, sebagai upaya penurunan penyimpangan produksi secara berkelanjutan.

\section{Daftar pustaka}

1. Badan Pengawas Obat dan Makanan Republik Indonesia. Cara Pembuatan Obat Yang Baik (CPOB); 2012.

2. Ann McGee. Human Error in Pharmaceutical 
Manufacturing. McGee Pharma International; 2010.

3. Quality Council Report PT. XXX. Quality Metric. Report date January 2016.

4. Quality Council Report PT. XXX. Quality Metric. Report date January 2017.

5. Quality Council Report PT. XXX. Quality Metric. Report date January 2018.

6. Delivery Council Report PT. XXX. Profit Plan Volume. Report date December 2016.

7. Site Master File PT. XXX. Issued date March 2015.

8. Frita YA. Job Instruction PT. XXX. Proses Kualifikasi Pelatihan di IPT B. JI-11-002-2.04. Effective date 26 January 2018.

9. Sugiyono. Metode Penelitian Pendidikan Pendekatan Kuantitatif, Kualitatif, dan R\&D. Bandung: Penerbit Alfabeta; 2010.

10. Dyah NAJ. Statistik Deskriptif dan Regresi Linier Berganda Dengan SPSS. Semarang: Semarang University Press; 2012.

11. David SJ. Statistik Farmasi. Jakarta: Penerbit
Buku Kedokteran EGC; 2010.

12. Nornadiah MR, Yap BW. Power Comparisons of Shapiro-Wilk, Kolmogorov-Smirnov, Lilliefors and Anderson-Darling Tests. Journal of Statistical Modeling and Analysis. 2011;2(1):21-33.

13. Asghar G, Saleh Z. Normality Test for Statistical Analysis : A Guide for Statisticians. Int J Endocrinol Metab, 2012;10(2):486-9.

14. Pradistya A. Periodic System Review PT. XXX. Blister Line A Packaging and Labeling SystemBlister Machine \#1. Period 2015-2017. PSR2017-00-Blister Machine \#1. Effective date 05 July 2017.

15. Pradistya A. Periodic System Review PT. XXX. Blister Line B Packaging and Labeling SystemBlister Machine \#2. Period 2015-2017. PSR2017-00-Blister Machine \#2. Effective date 02 October 2017.

16. Amir S, Muhammad K. Six Sigma Quality for Business Improvement. Yogyakarta: Graha Ilmu; 2013. 